\title{
Worker Empowerment Through Corporate Law?
}

\author{
Ownership and Control: Rethinking Corporate Governance for the Twenty-
} First Century. By Margaret M. Blair.* Washington, D.C.: The Brookings Institution, 1995. Pp. vii, 371. \$34.95 (hbk.), \$14.95 (pbk.).

Scholarly interest in corporate law has fluctuated during this century. In 1932, Adolf Berle and Gardiner Means defined the field for subsequent generations with their treatise on "the separation of ownership and control."1 Indeed, so influential was Berle and Means's work that corporate law became intellectually moribund in the postwar era, ${ }^{2}$ only to be revived when the lawand-economics movement turned its attention to the dilemma posed by the Berle-Means thesis. ${ }^{3}$ For most scholars, the agency problems between management and stockholders remain the critical issue, ${ }^{4}$ but Margaret M. Blair imaginatively applies law and economics to promote the cause of a different constituency: workers. Thus, Blair brings the debate over corporate law back to its normative roots in the legal realism of Berle and Means, who (as is often forgotten ${ }^{5}$ ) argued that the separation of ownership and control, by unbundling the traditional attributes of ownership, deprived stockholders of their sole claim to corporate profits and entitled the people to demand that corporations be managed in the interests of workers and "all society."

Ownership is the right to an asset's residual returns and to control over the asset (p. 27). ${ }^{7}$ Blair argues that stockholders are not a corporation's sole residual claimants and therefore should not be deemed its sole owners and granted exclusive control. Because many employees embody firm-specific

* Senior Fellow, Economic Studies Program, The Brookings Institution.

1. Adolf A. Berle \& Gardiner C. MEANS, The MODERN Corporation and PRIVATE PRoperty 5 (Transaction Publishers 1991) (1932). This book was "without question the most infiuential book on corporate America ever written." DANiEL R. FISCHEL, PAYBACK: THE CONSPIRACY TO DESTROY MICHAEL MILKEN AND HIS FINANCIAL REVOLUTION 12 (1995).

2. See Roberta Romano, Metapolitics and Corporate Law Reform, 36 STAN. L. REv. 923, 923 (1984).

3. Ralph K. Winter, Foreword to RobERTA ROMANO, THE GENIUS OF AMERICAN CORPORATE LAW at ix, ix-x (1993).

4. See, e.g., ROMANo, supra note 3 , at 1 .

5. See, e.g., FiSCHEL, supra note 1, at 12-14 (summarizing Berle-Means thesis as concemed with shareholder-management agency costs without mentioning normative position of Berle and Means).

6. BERLE \& MEANS, supra note 1, at 312; see also MORTON J. HORWIT, THE TRANSFORMATION OF AMERICAN LAW 1870-1960, at 166-67 (1992) (discussing normative position of Berle and Means); Romano, supra note 2, at 936-37 (same).

7. See, e.g., PaUl Milgrom \& JoHn Roberts, Economics, ORganization and Management 289-91 (1992). 
human capital, they too are rewarded with a share of the firm's residual returns (pp. 15-16, 230-32). ${ }^{8}$ Blair's argument that workers should be given a share of control and perhaps of equity ultimately falters on the impossibility of measuring firm-specific human capital, the difficulty of devising effective means of governance to maximize returns to diverse constituencies, and the existence of alternative ways of compensating workers for their firm-specific human capital. Nevertheless, Blair's provocative use of efficiency arguments to redefine employees as part-owners of their firms should stimulate further research and practical experimentation.

Blair emphasizes that, despite continuing debates in corporate law such as that over hostile takeovers, ${ }^{9}$ there is a nearly universal consensus among scholars that a corporation's primary goal is to maximize the value of the stockholders' shares (pp. 12, 95-115, 122). ${ }^{10}$ This is deemed a corporation's proper purpose because shareholders bear the residual risk and receive the residual returns from the firm's business (pp. 15, 228-29). Others who deal with a company, including employees, protect their interests by contract (p. 210). ${ }^{11}$ Stockholders' exposure to the hazards of the firm's business gives them the greatest incentive to monitor the firm to ensure that it maximizes profits. ${ }^{12}$ Thus, enhancing stock value should be corporations' goal.

Blair criticizes this consensus on efficiency grounds, drawing on the work of economists who have recognized the existence of firm-specific human capital for thirty years. ${ }^{13}$ She turns the economists' insight into a new basis for greater worker involvement in firms' governance, which some critics of corporate law have previously advocated on political grounds. ${ }^{14}$ Since some workers have firm-specific skills, she argues that, like stockholders, they share

8. Blair argues both that workers who have firm-specific skills often already share in residual returns, and that such workers should share in both residual returns (perhaps through stock ownership) and control (pp. 15-16, 326).

9. See, e.g., Frank H. Easterbrook \& Daniel R. Fischel, The Proper Role of a Target's Management in Responding to a Tender Offer, 94 HaRV. L. Rev. 1161 (1981) (arguing against permitting defensive tactics by target's management); Ronald J. Gilson, Seeking Competitive Bids Versus Pure Passivity in Tender Offer Defense, 35 STAN. L. REV. 51 (1982) (arguing that defensive tactics should be permitted to extent they facilitate competing bids without preventing takeovers); see also infra note 21 and accompanying text.

10. See, e.g., Frank H. Easterbrook \& Daniel R. Fischel, The Economic Structure of CORPORATE LAW 36, 67-70, 90-91 (1991); OLIVER E. WILliAMSON, THE ECONOMIC INSTITUTIONS OF CAPITALISM 298, 304-06 (1985).

11. EASTERBROOK \& FISCHEL, supra note 10 , at $36,90-91$.

12. Id. at $68,90-91$.

13. See GARY S. BECKER, HUMAN CAPITAL 19-20, 26 (2d ed. 1975). Becker's work distinguishing firm-specific from general human capital was first published in 1964.

14. See, e.g., ROBERT A. DAHL, AFTER THE REVOLUTION? 115-40 (1970). 
in the firm's residual returns (pp. 230-32). ${ }^{15}$ Accordingly, managing a firm so as to maximize only the residual gains to stockholders risks inefficiency in the event that the firm's revenues suffice to provide returns to firm-specific human capital but not to equity. Existing doctrine then encourages management to fire workers or even discontinue operations, squandering human capital that should remain productively employed (pp. 256-57). ${ }^{16}$

Blair therefore urges directors to recognize a duty to maximize returns to firm-specific human capital as well as equity (pp. 239-40, 324-26). Although she refers to changing "[t]he law and the culture of the boardroom" (p. 239), she advocates no major changes in corporate law; rather, she favors increasing employee ownership and control under existing laws. She urges firms to experiment with various ways of achieving this goal, such as employee stock ownership plans (ESOPs), worker-management committees, and corporate pension-fund investment in employees' own firms (pp. 328-37). She also urges a change in boards' conception of corporate purpose. Whether or not workers own stock, she argues, those with firm-specific human capital should be deemed stakeholders with rights to share in control of the firm and in its residual returns (but she does not clarify whether directors' duty to nonstockholder workers should be legally enforceable by some form of fiduciary duty transcending the employment contract) (p. 326).

\section{III}

The existing legal framework gives companies much flexibility to experiment with alternative structures and goals, as Blair urges. ESOPs and other forms of employee ownership are common. Like Blair's call for experimentation with corporate forms, her recommended attitudinal change is not necessarily radical, in light of the corporate culture that favors maximizing long-term entity value, as opposed to seeking short-term stock-price increases. ${ }^{17}$ Corporate law, as Blair notes, does not compel boards to act solely to maximize stockholder value (pp. $93,211-23$ ). A corporation may be

15. Firm-specific human capital is valuable only to the firm at which the workers have obtained it through training and experience. Once the workers develop such capital, therefore, they are in a position to bargain for compensation higher than the market value of their general human capital; the firm has an incentive to pay them such higher compensation, effectively sharing the quasi-rents generated by the firmspecific human capital (pp. 251,256-57). Blair argues that such compensation represents sharing in residual returns, since it is contingent on the success of the firm (pp. 231, 257), but her conclusion that workers' exposure to their employers' varying fortunes mandates giving them a share in control does not follow. See infra text accompanying notes 30-32.

16. Cf. Sidney G. Winter, Routines, Cash Flows, and Unconventional Assets: Corporate Change in the 1980s, in THE DEAL DECADE 55, 74-79 (Margaret M. Blair ed., 1993) (arguing that layoffs sacrificing human capital may be efficient if high interest rates depress such capital's value, but inefficient if long-term intangible value lost exceeds short-term cash gained).

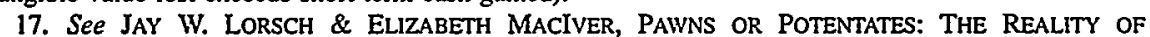
AMERICA'S CORPORATE BOARDS 43-47 (1989). 
chartered to pursue any lawful purpose, ${ }^{18}$ and many corporations (such as newspaper publishers) temper profit maximization with other social goals. ${ }^{19}$ During ordinary operations, directors owe fiduciary duties to the corporation and are free to weigh competing claims of employees, stockholders, and other constituents within the mantle of the business judgment rule (pp. 56-58). ${ }^{20}$ Even when a bidder for a firm offers stockholders a premium for their shares, the target board has some discretion to weigh the interests of stakeholders such as employees in deciding whether to resist the offer. ${ }^{21}$

Yet Blair is surely right that the prevailing attitude informing corporate law remains that corporations are to serve the stockholders by maximizing share value..$^{22}$ Thus, only stockholders may legally enforce directors' fiduciary duties, while employees are left to their contracts. ${ }^{23}$ Widespread corporate layoffs, even in profitable firms at a time of economic growth, dramatize the vulnerability of human capital under existing law.

Nevertheless, Blair's argument that workers should share in control and residual returns suffers from several weaknesses. First, as she admits, economists have yet to devise a reliable measure of firm-specific human capital (p. 263). ${ }^{24}$ Since (as Blair acknowledges) workers are compensated for their general skills by their contractual pay and benefits (pp. 230, 263-65), the inability separately to measure firm-specific skills undermines her claim that appropriate shares in residual returns and control, commensurate with firmspecific skills, can be determined. Financial capital is homogeneous and quantifiable, so it is simple to apportion both votes and dividend and

18. Robert C. Clark, Corporate LAW $\$ 1.2 .3$, at 17 (1986); see also DEL. CODE ANN. tit. 8 , $\S 102(a)(3)(1994)$.

19. See EASTERBROOK \& FISCHEL, supra note 10 , at 36.

20. See 1 R. FrankLin Balotti \& JesSe A. Finkelstein, The Delaware LaW of Corporations AND BuSINESS ORGANIZATIONS $\$ 4.6$, at 4-56 to 4-58 (2d ed. 1990 \& Supp. 1995) (noting broad directorial discretion to manage corporation for any rational business purpose, perhaps even for sole benefit of workers); PAUL C. WEILER, GOVERNING THE WORKPLACE 162 (1990) (same).

21. In the middle of the 1980s takeover wave, the Supreme Court of Delaware, the leading state of incorporation for large firms, held that target boards could consider takeover bids' impact on constituencies other than stockholders in deciding whether to resist offers. See Unocal Corp. v. Mesa Petroleum Co., 493 A.2d 946, 955 (Del. 1985). The court soon limited this aspect of board discretion, holding that once a firm is for sale, its board may consider other constituencies' interests only to the extent such consideration is rationally related to benefiting stockholders. See Revlon, Inc. v. MacAndrews \& Forbes Holdings, 506 A.2d 173, 182 (Del. 1986). Despite Revlon, targets' directors may still weigh interests other than those of stockholders in deciding to resist the sale of their firms. See Ivanhoe Partners v. Newmont Mining Corp., 535 A.2d 1334, 1341-42 (Del. 1987); see also 1 BALOTTI \& FINKELSTEIN, supra note 20, $\$ 4.6$, at 4-58 n.206 (discussing Delaware case law on targets' consideration of nonstockholder constituencies in responding to takeover offers). For a discussion of other states' antitakeover "stakeholder" statutes, see ROMANO, supra note 3 , at 56.

22. See I BALOTTI \& FINKELSTEIN, supra note $20, \$ 4.10(\mathrm{C})(5)$ at 4-247; CLARK, supra note 18 , $\S$ 1.2.3, at 17-18; RichaRd A. POSNER, ECONOMIC ANALYSIS OF LAW 419-21 (4th ed. 1992); WEILER, supra note 20 , at $161-62$.

23. See, e.g., ROMANO, supra note 3 , at 58 (noting that antitakeover stakeholder statutes do not create enforceable rights for workers).

24. See Lester C. THUROW, INVEStMENT IN HuMan CAPITAL 92 (1970); Sherwin Rosen, Transactions Costs and Internal Labor Markets, 4 J.L. ECON. \& ORGANIZATION 49, 51 (1988). 
liquidation rights among stockholders. ${ }^{25}$ Human capital, by contrast, is difficult to measure, diverse, and often not attributable to any particular employee or group of employees. ${ }^{26}$ The inability to measure firm-specific human capital suggests that negotiated compensation in a competitive labor market is the best measure of an employee's value to the firm, i.e., his or her marginal productivity. ${ }^{27}$ Giving workers control rights with which to appropriate a share of a firm's profits risks overcompensating them relative to their productivity.

Making firms answerable to different groups with diverse, sometimes hostile interests (such as investors and various categories of workers) would also impose substantial management costs as participants struggled to set policy and allocate rewards among themselves. ${ }^{28}$ Blair acknowledges this problem (p. 326), but her sanguine acceptance of the fragmentation of corporate boards into rival factions representing labor and capital is unpersuasive. Corporations with conflicting goals and divided boards would surely be less efficient than those devoted primarily to seeking profits and directed by boards answerable to one group alone.

Finally, Blair's argument that workers with firm-specific skills should be given new rights to control their firms and share in profits does not adequately acknowledge that such workers already are rewarded for their firm-specific skills, and that there are important reasons for using arm's-length bargaining rather than employee ownership to determine worker compensation. Blair does not refute the orthodox claim that workers are contractually compensated for their firm-specific as well as transferable skills. ${ }^{29}$ Indeed, she cites evidence that they are compensated (pp. 230-31). If workers have already bargained for payment for their special skills, however, claiming a share of control and equity as compensation for the same skills is double dipping. Blair argues that the existence of compensation packages that are more generous than employees could receive for their general skills at rival firms demonstrates that workers share in residual returns and should therefore be granted a commensurate share (1988)

25. See Henry Hansmann, Ownership of the Firm, 4 J.L. ECON. \& ORGANizATION 267, 277-80, 283

26. See THUROW, supra note 24 , at 93 (noting that workers' knowledge of firm-specific physical capital is firm-specific human capital); WILLIAMSON, supra note 10, at 246-47 (noting that teamwork skilts are one form of firm-specific human capital); Ronald J. Gilson \& Robert H. Mnookin, Sharing Among the Human Capitalists: An Economic Inquiny into the Corporate Law Firm and How Partners Split Profits, 37 STAN. L. REv. 313, 357, 368 (1985) (noting that such firm-specific human capital as reputation and client relationships often resides in firm as whole); Benjamin Klein, Vertical Integration as Organizational Ownership: The Fisher Body-General Motors Relationship Revisited, 4 J.L. ECON. \& ORGANIZATION 199, 207-08 (1988) (arguing that firm-specific team expertise not attributable to individual or small group capable of withholding it is owned by equity owners of firm).

27. Cf. Hansmann, supra note 25, at 295-96 (noting difficulty of measuring employee productivity in employee-owned firms where workers' skills are diverse).

28. See EASTERBROOK \& FISCHEL, supra note 10, at 38,69-70; WILLIAMSON, supra note 10, at 311-12, 324; Hansmann, supra note 25, at 294-95.

29. See, e.g., MILGROM \& ROBERTS, supra note 7, at 332-33, 345. 
of control to protect their stake in these returns (pp. 230-31). Employees who receive contractual compensation for their firm-specific human capital, however, by definition do not share in residual returns. ${ }^{30}$ To the extent that compensation for firm-specific skills is not fired but contingent, such pay is better understood not as an attribute of ownership, but as a form of bonding to control the moral hazard of shirking and as a bargained sharing of the profits generated by such skills so as to maintain the relationship between workers and firm. This is advantageous to both sides because workers with such skills are more productive at their current employer both than they would be elsewhere, and than new hires lacking their skills. ${ }^{31}$ Protecting workers' interests in such contingent compensation by means of a share in control, rather than by means of the ongoing, incomplete contract between workers and the firm, would vitiate the compensation's bonding effect and impair the firm's flexibility when changed circumstances reduce the skills' value. ${ }^{32}$

\section{IV}

Blair does not employ the leftist rhetoric of earlier advocates of worker self-determination. ${ }^{33}$ Only rarely does she hint that normative concerns other than efficiency might motivate her commitment to enhancing the status of employees in corporate decisionmaking: '[E]mployees who embody [a firm's] critical resources have important and inalienable control rights over the use of those resources" (p. 292) (emphasis added). In today's political and intellectual climate, such an argument can only hope for success if it is couched in the fashionable language of law and economics. Blair's work is not fully successful, but it should entice sympathetic economists to refine their yardsticks of human capital and corporate architects to experiment with new forms of worker participation. Such experimentation is her major goal (pp. 337-38), and organizational experimentation under flexible laws in a market economy is the best way to allow efficient firms to evolve. ${ }^{34}$

-Jai K. Chandrasekhar

30. See id. at 291 .

31. See id. at 214, 333; Oliver D. Hart, Incomplete Contracts and the Theory of the Firm, 4 J.L. ECON. \& ORGANIZATION 119, 125 (1988).

32. $C f$. EASTERBROOK \& FISCHEL, supra note 10, at 38-39 (arguing that layoffs enhance efficiency of firms individually and collectively, enhancing economy's net ability to sustain employment); FISCHEL, supra note 1, at 33 (same); Harold Demsetz, The Theory of the Firm Revisited, 4 J.L. ECoN. \& ORGANIZATION 141, 153-54 (1988) (discussing corporate takeovers' role in eliminating firm-specific human capital no longer needed for productivity).

33. See, e.g., Charles A. Reich, The Greening of America 314, 345 (1970); Jaroslav Vanek, THE PARTICIPATORY ECONOMY 94, 106-13 (1971).

34. See ROMANO, supra note 3, at 9, 148-51; WILlIAMSON, supra note 10, at 295. 